\title{
KECEMASAN REMAJA PADA MASA PANDEMI COVID-19
}

\author{
Joseph Henokh Ruskandi \\ Fakultas Ilmu Keperawatan, Universitas Advent Indonesia, Jl. Kolonel Masturi No.288, Cihanjuang \\ Rahayu, Kec. Parongpong, Kabupaten Bandung Barat, Jawa Barat 40559, Indonesia \\ 1751012@unai.edu (+6282115099006)
}

\begin{abstract}
ABSTRAK
Corona Virus Disease 2019 atau biasa dikenal dengan sebutan COVID-19 adalah sebuah penyakit menular yang disebabkan oleh SARS CoV-2, salah satu jenis koronavirus yang dapat menyebar antara orang-orang melalui percikan pernapasan (droplet). Sejak WHO menyatakan Covid-19 sebagai pendemic global, semua aktivitas dan kegiatan yang biasanya dilakukan di luar rumah tiba-tiba menjadi harus dilakukan dari rumah yang tentunya berdampak pada kecemasan semua kalangan termasuk remaja. Dalam penelitian ini, penulis bertujuan mengungkapkan tentang kondisi kecemasan yang dialami oleh remaja beserta dengan faktorfaktor yang mempengaruhi kecemasan pada masa COVID-19 dengan melakukan kajian terhadap 14 jurnal terkait kecemasan remaja. Jurnal ini diperoleh dari database Google Scholar. Hasil yang diperoleh adalah rata-rata remaja mengalami kecemasan pada kategori ringan. Remaja yang memiliki tingkat kecemasan ringan biasanya memiliki tingkat pengetahuan terkait pandemic covid-19 yang lebih baik, memiliki hubungan yang baik dengan lingkungan dan keluarga, memiliki koping yang baik serta memiliki tingkat religiusitas yang baik.
\end{abstract}

Kata kunci: covid-19; kecemasan; remaja

\section{ADOLESCENT ANXIETY DURING THE COVID-19 PANDEMIC}

\section{ABSTRACT}

Corona Virus Disease 2019 or commonly known as COVID-19 is an infectious disease caused by SARS CoV-2, a type of coronavirus that can spread between people through respiratory droplets (droplets). Since WHO declared Covid-19 as a global pandemic, all activities and activities that are usually carried out outside the home suddenly have to be done from home which of course has an impact on the anxiety of all groups including teenagers. In this study, the author aims to reveal about the anxiety conditions experienced by adolescents along with the factors that influence anxiety during the COVID-19 period by conducting a study of 14 journals related to adolescent anxiety. This journal was obtained from the Google Scholar database. The results obtained are the average adolescent experiencing anxiety in the mild category. Adolescents who have mild anxiety levels usually have a better level of knowledge related to the COVID-19 pandemic, have good relationships with the environment and family, have good coping and have a good level of religiosity.

Keywords: adolescents; anxiety; covid-19

\section{PENDAHULUAN}

Corona Virus Disease 2019 atau biasa dikenal dengan sebutan COVID-19 adalah sebuah penyakit menular yang disebabkan oleh SARS CoV-2, salah satu jenis koronavirus yang dapat menyebar antara orang-orang melalui percikan pernapasan (droplet). Sejak Maret 2020, WHO telah menyatakan bahwa COVID-19 sebagai pandemic global. Berbagai macam upaya telah dilakukan guna menghentikan mata rantai penyebaran virus antara lain seperti dengan mengikuti protocol 
kesehatan, tidak panik, tetap menjaga kesehatan, menghindari keramaian dan menjaga jarak, serta memperkuat imunitas tubuh (Mahfud \& Gumantan, 2020). Selain dari kebijakan yang telah dibuat oleh pemerintah, perlu adanya respon balik dari masyarakat serta komitmen untuk dapat patuh terhadap kebijakan yang telah dibuat (Harirah \& Rizaldi, 2020). Namun, keadaan yang berubah secara tiba-tiba membuat masyarakat tidak siap menghadapinya baik secara fisik maupun psikis (Sabir \& Phill, 2016). Keadaan dimana kita tidak bisa mengetahui dengan pasti apa yang akan terjadi memang bisa menjadi pemicu atau penyebab dari kecemasan.

Kecemasan adalah keadaan ketika emosi negative muncul akibat kekhawatiran akan bahaya yang tidak terduga yang mungkin terjadi di masa depan (Annisa \& Ifdil, 2017). Kecemasan sebenarnya adalah perasaan yang normal dimiliki oleh manusia, karena saat cemas manusia disadarkan dan diingatkan tentang bahaya yang mengancam (Suwandi \& Malinti, 2020). Namun kecemasan yang berlebihan dapat mengganggu dalam proses belajar karena perasaan takut dan khawatir akan suatu hal, yang dalam kondisi saat ini adanya pandemic COVID-19 yang dapat mempengaruhi konsentrasi dan daya ingat (Mahfud \& Gumantan, 2020).

Sesuai dengan kebijakan physical distancing atau menjaga jarak demi mencegah penyebaran COVID-19, maka Kementrian Pendidikan dan Kebudayaan dalam Surat Edaran Nomor 36962/MPK.A/HK/2020 mengatakan bahwa pembelajaran dilakukan secara daring dari rumah. Semua aktivitas kegiatan yang biasanya dilakukan di luar rumah tiba-tiba menjadi harus dilakukan dari rumah. Perubahan kondisi baru yang diikuti dengan berbagai macam permasalahan baru yang belum pernah dihadapi menjadi sebuah tantangan baru bagi remaja untuk bisa terus mengikuti dan beradaptasi dengan perubahan yang terjadi (Fauziyyah et al. 2021).

Menurut World Health Organization (WHO), rentang usia remaja adalah 1019 tahun; menurut Peraturan Mentri Kesehatan RI Nomor 25 tahun 2014, rentang usia remaja adalah 10-18 tahun; menurut Badan Kependudukan dan Keluarga Berencana (BKKBN), rentang usia remaja adalah 10-24 tahun dan belum menikah. Jadi, seseorang dapat dikatakan remaja karena sudah tidak bisa lagi disebut kanak-kanak namun, belum cukup matang untuk dapat dikatakan dewasa atau bisa dibilang sebagai masa peralihan dari kanakkanak ke dewasa (Sumara et al. 2017). Dalam masa peralihan ini, remaja sangat rentan dalam mengalami gangguan kesehatan berupa kecemasan. Ditambah dengan kondisi dimana pembelajaran harus dilakukan secara daring, kecemasan dapat bertambah seperti kecemasan akibat perubahan lingkungan belajar, tugas pembelajaran yang berat, tidak siapnya menghadapi gaya belajar yang baru, serta menurunnya minat dan konsentrasi dalam belajar (Ilahi et al. 2021). Dalam penelitian ini, penulis bertujuan mengungkapkan tentang kondisi kecemasan yang dialami oleh remaja beserta dengan faktor-faktor yang mempengaruhi kecemasan pada masa COVID-19.

\section{METODE}

Metode yang digunakan dalam penulisan studi literatur ini melalui penelusuran internet dari database Google Scholar dari tahun 2020sekarang dengan menggunakan kata 
kunci kecemasan remaja pada masa pandemic COVID-19.

Hasil penelusuran yang telah dilakukan dengan menggunakan kata kunci yang telah ditentukan, terdapat total hasil penelusuran sebanyak 1050 artikel. Dari jumlah 1050 artikel yang didapatkan dari Google Scholar, peneliti melakukan skrining berdasarkan tahun dan didapati hasil sebanyak 1000 artikel. Sebanyak 939 artikel dieksklusikan karena judul yang didapati tidak relevan, dan didapati sebanyak 27 artikel tanpa akses full text, kemudian sebanyak 20 artikel yang tidak memenuhi kriteria yang telah ditentukan, dan didapati hasil akhir sebanyak 14 artikel.

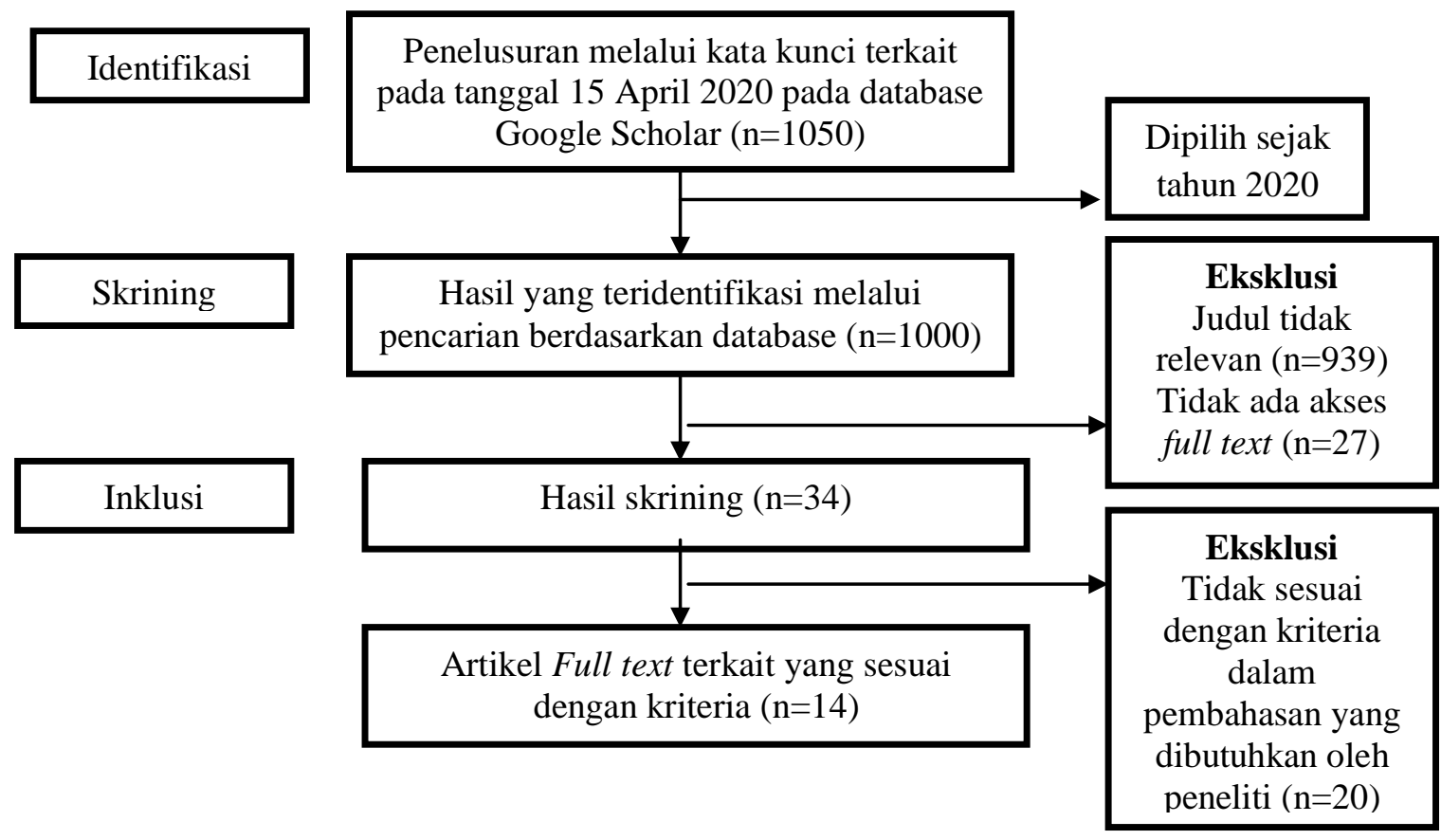

HASIL

Hasil studi literatur ini, diambil sebanyak 14 sampel penelitian yang terkait dengan tingkat kecemasan remaja pada masa pandemic COVID19. Berikut hasil penelitian akan dipaparkan :

Tabel 1.

Hasil Analisis Artikel

\begin{tabular}{|c|c|c|c|c|c|}
\hline No. & $\begin{array}{l}\text { Penulis } \\
\text { (Tahun) }\end{array}$ & Judul & $\begin{array}{l}\text { Jumlah } \\
\text { sampel }\end{array}$ & $\begin{array}{l}\text { Instrument } \\
\text { penelitian }\end{array}$ & Hasil \\
\hline 1. & $\begin{array}{l}\text { Linda Fitria } \\
\text { dan Ifdil Ifdil } \\
\quad(2020)\end{array}$ & $\begin{array}{l}\text { Kecemasan } \\
\text { remaja pada } \\
\text { masa pandemic } \\
\text { Covid-19 }\end{array}$ & 139 & $\begin{array}{l}\text { Skala } \\
\text { Kecemasan } \\
\text { Remaja }\end{array}$ & $\begin{array}{l}\text { Tingkat kecemasan } \\
\text { yang dialami remaja } \\
\text { pada masa pandemic } \\
\text { Covid-19 berdasakan } \\
\text { pada kategori rendah } \\
\text { sebesar } 2.1 \% \text {, kategori } \\
\text { sedang } 43.9 \% \text { dan } \\
\text { kategori tinggi } 54 \% \text {. }\end{array}$ \\
\hline
\end{tabular}




\begin{tabular}{|c|c|c|c|c|c|}
\hline No. & $\begin{array}{l}\text { Penulis } \\
\text { (Tahun) }\end{array}$ & Judul & $\begin{array}{l}\text { Jumlah } \\
\text { sampel }\end{array}$ & $\begin{array}{l}\text { Instrument } \\
\text { penelitian }\end{array}$ & Hasil \\
\hline 2. & $\begin{array}{c}\text { Erna } \\
\text { Febriyanti } \\
\text { dan Artanty } \\
\text { Mellu (2020) }\end{array}$ & $\begin{array}{l}\text { Tingkat } \\
\text { kecemasan } \\
\text { mahasiswa } \\
\text { keperawatan } \\
\text { dalam } \\
\text { menghadapi } \\
\text { pandemi Covid- } \\
19 \text { di kota } \\
\text { Kupang }\end{array}$ & 171 & $\begin{array}{l}\text { Kuesioner } \\
\text { online }\end{array}$ & $\begin{array}{lr}\text { Tingkat } & \text { kecemasan } \\
\text { yang } & \text { dialami } \\
\text { mahasiswa pada masa } & \text { pandemic } \\
\text { povid-19 } \\
\text { berdasarkan kategori } \\
\text { sedang sebesar } 56.7 \% \\
\text { dan kategori rendah } \\
43.3 \% \text {. }\end{array}$ \\
\hline 3. & $\begin{array}{c}\text { Dhini } \\
\text { Amynarti } \\
\text { Wardiani, } \\
\text { Sahuri Teguh } \\
\text { Kurniawan, } \\
\text { dan Irna } \\
\text { Kartina } \\
\text { (2020) }\end{array}$ & $\begin{array}{l}\text { Gambaran } \\
\text { tingkat } \\
\text { kecemasan } \\
\text { mahasiswa } \\
\text { keperawatan } \\
\text { Universitas } \\
\text { Kusuma Husada } \\
\text { Surakarta saat } \\
\text { menjalani skripsi } \\
\text { di masa } \\
\text { pandemic Covid- } \\
19\end{array}$ & 166 & $\begin{array}{l}\text { Kuesioner } \\
\text { kecemasan }\end{array}$ & $\begin{array}{l}\text { Tingkat kecemasan } \\
\text { yang dialami } \\
\text { mahasiswa pada masa } \\
\text { pandemic Covid-19 } \\
\text { berdasarkan kategori } \\
\text { normal / tidak cemas } \\
\text { sebesar } 38.8 \% \text {, ringan } \\
8.6 \% \text {, sedang } 23.3 \% \text {, } \\
\text { berat } 15.5 \%, \text { dan } \\
\text { sangat berat } 13.5 \% \text {. }\end{array}$ \\
\hline 4. & $\begin{array}{l}\text { Devra Jovana } \\
\text { Clarissa } \\
\text { Suryaatmaja } \\
\text { dan Imanuel } \\
\text { Sri Wei } \\
\text { Wulandari } \\
(2020)\end{array}$ & $\begin{array}{l}\text { Hubungan } \\
\text { Tingkat } \\
\text { Kecemasan } \\
\text { Terhadap Sikap } \\
\text { Remaja Akibat } \\
\text { Pandemik Covid- } \\
19\end{array}$ & 51 & $\begin{array}{l}\text { Kuesioner } \\
\text { tingkat } \\
\text { kecemasan }\end{array}$ & $\begin{array}{l}\text { Tingkat } \text { kecemasan } \\
\text { yang dialami oleh } \\
\text { remaja pada masa } \\
\text { pandemic Covid-19 } \\
\text { berdasarkan kategori } \\
\text { normal / tidak cemas } \\
\text { sebesar } 2.0 \% \text {, ringan } \\
29.4 \% \text {, sedang } 64.7 \% \text {, } \\
\text { dan berat } 3.9 \% \text {. }\end{array}$ \\
\hline 5. & $\begin{array}{l}\text { Astrid Dinda } \\
\text { Wahyu Ilahi, } \\
\text { Visalia } \\
\text { Rachma, } \\
\text { Worohayun } \\
\text { Janastri, dan } \\
\text { Usmi } \\
\text { Karyanti } \\
\text { (2021) }\end{array}$ & $\begin{array}{l}\text { The level of } \\
\text { anxiety of } \\
\text { students during } \\
\text { the Covid-19 } \\
\text { pandemic: } \\
\text { tingkat } \\
\text { kecemasan } \\
\text { mahasiswa di } \\
\text { masa pandemic } \\
\text { Covid-19 }\end{array}$ & 530 & $\begin{array}{l}\text { Depression } \\
\text { Anxiety } \\
\text { Stress Scale } \\
\text { (DASS) }\end{array}$ & $\begin{array}{l}\text { Tingkat kecemasan } \\
\text { yang dialami } \\
\text { mahasiswa pada masa } \\
\text { pandemic Covid-19 } \\
\text { berdasakan pada } \\
\text { kategori normal / tidak } \\
\text { cemas sebesar 48\%, } \\
\text { ringan } 18 \% \text {, sedang } \\
26 \% \text {, berat } 7 \% \text {, dan } \\
\text { sangat berat } 1 \% \text {. }\end{array}$ \\
\hline 6. & $\begin{array}{c}\text { Irma Maya } \\
\text { Puspita, } \\
\text { Annisa } \\
\text { Wigati } \\
\text { Rofiza, dan } \\
\text { A'im Matun }\end{array}$ & $\begin{array}{l}\text { Gambaran } \\
\text { kecemasan dan } \\
\text { kepatuhan remaja } \\
\text { putri terhadap } \\
\text { kebiasaan baru } \\
\text { pada masa }\end{array}$ & 95 & $\begin{array}{l}\text { Zung Self- } \\
\text { rating } \\
\text { Anxiety } \\
\text { Scale } \\
\text { (ZSAS) }\end{array}$ & $\begin{array}{l}\text { Tingkat kecemasan } \\
\text { yang dialami oleh } \\
\text { remaja pada masa } \\
\text { pandemic Covid-19 } \\
\text { berdasarkan kategori } \\
\text { ringan sebesar 80\%, }\end{array}$ \\
\hline
\end{tabular}




\begin{tabular}{|c|c|c|c|c|c|}
\hline No. & $\begin{array}{l}\text { Penulis } \\
\text { (Tahun) }\end{array}$ & Judul & $\begin{array}{l}\text { Jumlah } \\
\text { sampel }\end{array}$ & $\begin{array}{l}\text { Instrument } \\
\text { penelitian }\end{array}$ & Hasil \\
\hline & $\begin{array}{l}\text { Nadhiroh } \\
(2021)\end{array}$ & $\begin{array}{l}\text { pandemic Covid- } \\
19 \text { di Surabaya }\end{array}$ & & & $\begin{array}{lcc}\text { sedang } & 8.4 \%, & \text { berat } \\
10.5 \%, & \text { dan } & \text { panik } \\
1.1 \% \text {. } & & \\
\end{array}$ \\
\hline 7. & $\begin{array}{c}\text { Ari } \\
\text { Pamungkas } \\
(2020)\end{array}$ & $\begin{array}{l}\text { Tipe kepribadian } \\
\text { ekstrovert- } \\
\text { introvert dan } \\
\text { kecemasan } \\
\text { mahasiswa pada } \\
\text { masa pandemic } \\
\text { Covid-19 }\end{array}$ & 100 & $\begin{array}{l}\text { Depression } \\
\text { Anxiety } \\
\text { Stress Scale } \\
\text { (DASS) } 21\end{array}$ & $\begin{array}{l}\text { Tingkat kecemasan } \\
\text { yang dialami oleh } \\
\text { mahasiswa pada masa } \\
\text { pandemic Covid-19 } \\
\text { berdasarkan kategori } \\
\text { normal / tidak cemas } \\
\text { sebesar } 21 \% \text {, ringan } \\
5 \% \text {, sedang } 7 \% \text {, berat } \\
19 \% \text {, sangat berat } \\
48 \% \text {. }\end{array}$ \\
\hline 8. & $\begin{array}{c}\text { Syami } \\
\text { Yulianti dan } \\
\text { Lezi Yovita } \\
\text { Sari (2020) }\end{array}$ & $\begin{array}{l}\text { Hubungan } \\
\text { pengetahuan dan } \\
\text { perilaku dengan } \\
\text { tingkat } \\
\text { kecemasan } \\
\text { remaja terhadap } \\
\text { Covid-19 pada } \\
\text { siswa di } \\
\text { Pesantren } \\
\text { Pancasila Kota } \\
\text { Bengkulu }\end{array}$ & 32 & $\begin{array}{l}\text { Kuesioner } \\
\text { online }\end{array}$ & $\begin{array}{l}\text { Tingkat kecemasan } \\
\text { yang dialami oleh } \\
\text { remaja pada masa } \\
\text { pandemic Covid-19 } \\
\text { berdasarkan kategori } \\
\text { normal / tidak cemas } \\
\text { sebesar } 53.1 \% \text {, ringan } \\
18.8 \% \text {, sedang } 12.5 \% \text {, } \\
\text { berat } 15.6 \% \text {. }\end{array}$ \\
\hline 9. & $\begin{array}{l}\text { Aulia Mega } \\
\text { Safira (2020) }\end{array}$ & $\begin{array}{l}\text { Pengaruh fungsi } \\
\text { keluarga dan } \\
\text { pendapatan } \\
\text { keluarga } \\
\text { terhadap tingkat } \\
\text { kecemasan } \\
\text { remaja di era } \\
\text { pandemic Covid- } \\
19\end{array}$ & 87 & $\begin{array}{l}\text { Kuesioner } \\
\text { online }\end{array}$ & $\begin{array}{l}\text { Tingkat kecemasan } \\
\text { yang dialami oleh } \\
\text { remaja pada masa } \\
\text { pandemic Covid-19 } \\
\text { berdasarkan kategori } \\
\text { normal / tidak cemas } \\
\text { sebesar } 70.1 \% \text { dan } \\
\text { kategori cemas sebesar } \\
29.9 \% \text {. }\end{array}$ \\
\hline 10. & $\begin{array}{c}\text { Gheralyn } \\
\text { Regina } \\
\text { Suwandi dan } \\
\text { Evelin } \\
\text { Malinti } \\
(2020)\end{array}$ & $\begin{array}{l}\text { Hubungan } \\
\text { tingkat } \\
\text { pengetahuan } \\
\text { dengan tingkat } \\
\text { kecemasan } \\
\text { terhadap Covid- } \\
19 \text { pada remaja } \\
\text { di SMA Advent } \\
\text { Balikpapan }\end{array}$ & 60 & $\begin{array}{l}\text { Hamilton } \\
\text { Anxiety } \\
\text { Rating } \\
\text { Scale } \\
\text { (HARS) }\end{array}$ & $\begin{array}{l}\text { Tingkat kecemasan } \\
\text { yang dialami remaja } \\
\text { pada masa pandemic } \\
\text { Covid-19 berdasarkan } \\
\text { kategori ringan sebesar } \\
70.1 \% \text {, sedang } 21.6 \% \text {, } \\
\text { dan berat } 8.3 \% \text {. }\end{array}$ \\
\hline 11. & $\begin{array}{c}\text { Indri } \\
\text { Wahyuni, } \\
\text { Sutarno, dan } \\
\text { Rully Andika }\end{array}$ & $\begin{array}{l}\text { Hubungan } \\
\text { tingkat } \\
\text { religiusitas } \\
\text { dengan tingkat }\end{array}$ & 84 & $\begin{array}{l}\text { Zung Self- } \\
\text { rating } \\
\text { Anxiety } \\
\text { Scale }\end{array}$ & $\begin{array}{lr}\text { Tingkat } & \text { kecemasan } \\
\text { yang } & \text { dialami } \\
\text { mahasiswa } & \text { pada masa } \\
\text { pandemic } & \text { Covid-19 }\end{array}$ \\
\hline
\end{tabular}




\begin{tabular}{|c|c|c|c|c|c|}
\hline No. & $\begin{array}{l}\text { Penulis } \\
\text { (Tahun) }\end{array}$ & Judul & $\begin{array}{l}\text { Jumlah } \\
\text { sampel }\end{array}$ & $\begin{array}{l}\text { Instrument } \\
\text { penelitian }\end{array}$ & Hasil \\
\hline & (2020) & $\begin{array}{l}\text { kecemasan } \\
\text { mahasiswa di } \\
\text { masa pandemic } \\
\text { Covid-19 }\end{array}$ & & (ZSAS) & $\begin{array}{l}\text { berdasarkan kategori } \\
\text { normal / tidak cemas } \\
\text { sebesar } 58.3 \% \text {, ringan } \\
40.5 \% \text {, sedang } 1.2 \% \text {, } \\
\text { berat } 0 \% \text {. }\end{array}$ \\
\hline 12. & $\begin{array}{l}\text { Wilda Rezki } \\
\text { Pratiwi dan } \\
\text { Asmah } \\
\text { Sukarta } \\
(2020)\end{array}$ & $\begin{array}{l}\text { Hubungan } \\
\text { pemberitaan } \\
\text { media sosial } \\
\text { terhadap tingkat } \\
\text { kecemasan } \\
\text { perempuan pada } \\
\text { masa pandemic } \\
\text { Covid-19 }\end{array}$ & 51 & $\begin{array}{l}\text { Zung Self- } \\
\text { rating } \\
\text { Anxiety } \\
\text { Scale } \\
\text { (ZSAS) }\end{array}$ & $\begin{array}{l}\text { Tingkat kecemasan } \\
\text { yang dialami } \\
\text { mahasiswi pada masa } \\
\text { pandemic Covid-19 } \\
\text { berdasarkan kategori } \\
\text { ringan sebesar 0\%, } \\
\text { sedang } 2.0 \% \text {, berat } \\
23.5 \% \text {, panik } 74.5 \% \text {. }\end{array}$ \\
\hline 13 & $\begin{array}{l}\text { Imam } \\
\text { Mahfud dan } \\
\text { Aditya } \\
\text { Gumantan } \\
\text { (2020) }\end{array}$ & $\begin{array}{l}\text { Survey Of } \\
\text { Student Anxiety } \\
\text { Levels During } \\
\text { The Covid-19 } \\
\text { Pandemic }\end{array}$ & 110 & $\begin{array}{l}\text { Kuesioner } \\
\text { online }\end{array}$ & $\begin{array}{lr}\text { Tingkat } & \text { kecemasan } \\
\text { yang } & \text { dialami } \\
\text { mahasiswa pada masa } \\
\text { pandemic } & \text { Covid-19 } \\
\text { berdasarkan } & \text { kategori } \\
\text { sangat tidak cemas } & \text { cemas } \\
\text { sebesar } 9 \%, & \text { tidak } \\
\text { cemas 20.5\%, cemas } \\
34.1 \%, \text { dan sangat } \\
\text { cemas 36.4\%. }\end{array}$ \\
\hline 14. & $\begin{array}{l}\text { Andre Setya } \\
\text { Aji, Sahuri } \\
\text { Teguh } \\
\text { Kurniawan, } \\
\text { dan Maria } \\
\text { Wisnu } \\
\text { Kanita } \\
\text { (2021) }\end{array}$ & $\begin{array}{l}\text { Pengaruh virtual } \\
\text { reality terhadap } \\
\text { tingkat } \\
\text { kecemasan } \\
\text { mahasiswa dalam } \\
\text { menghadapi } \\
\text { tugas akhir di } \\
\text { masa pandemic } \\
\text { Covid-19 }\end{array}$ & 47 & $\begin{array}{l}\text { Depression } \\
\text { Anxiety } \\
\text { Stress Scale } \\
\text { (DASS) } 42\end{array}$ & $\begin{array}{l}\text { Tingkat kecemasan } \\
\text { yang dialami } \\
\text { mahasiswa pada masa } \\
\text { pandemic Covid-19 } \\
\text { berdasarkan kategori } \\
\text { ringan sebesar } 29.8 \% \text {, } \\
\text { dan sedang } 70.2 \% .\end{array}$ \\
\hline
\end{tabular}

\section{PEMBAHASAN}

Hasil tinjauan terhadap 14 jurnal diatas, terdapat rata-rata tiga kategori tingkat kecemasan yang dialami oleh remaja selama masa pandemic covid-19 yaitu ringan, sedang dan berat. Dari ketiga kategori ini, didapati modus tingkat kecemasan remaja berada pada kategori ringan kemudian berat dan yang terakhir sedang. Ada beberapa factor yang menjadi penyebab dari terjadinya kecemasan pada remaja pada saat pandemic covid-19 ini. Salah satu factor penyebab dari terjadinya kecemasan pada remaja adalah karena kurangnya informasi yang didapat (Fitria \& Ifdil, 2020; Suwandi \& Malinti, 2020; Yulianti \& Sari, 2020; Puspita et. al, 2021; Ilahi et. al, 2021; Mahfud \& Gumantan, 2020). Selain itu, informasi palsu (hoax) juga turut menyumbang peran penting sebagai factor penyebab terjadinya kecemasan. Berita-berita terkait covid-19 yang dengan cepat beredar di media sosial (infodemik) kebanyakan bersifat negative yang 
menimbulkan ketakutan dan kekhawatiran (Ari Pamungkas, 2020; Fitria \& Ifdil, 2020; Suwandi \& Malinti, 2020; Puspita et. al, 2021; Yulianti \& Sari, 2020; Pratiwi \& Sukarta, 2020; Wahyuni et. al, 2020; Mahfud \& Gumantan, 2020). Saat menerima atau mencari berita terkait dengan covid-19 perlu diperhatikan dengan baik kebenaran dan kejelasan dari berita tersebut, apalagi jika ingin menyebarkan informasi karena jika ternyata informasi yang disebarkan ternyata informasi palsu maka dapat menyebarkan kepanikan.

Faktor selanjutnya yaitu hubungan yang baik dengan lingkungan sekitar atau dengan keluarga memberikan tambahan pengaruh positif dalam menghadapi situasi dan mengurangi tingkat kecemasan (Ari Pamungkas, 2020; Suwandi \& Malinti, 2020; Aji et. al, 2021; Aulia Mega, 2020; Ilahi et. al, 2021). Dukungan dari keluarga serta koping positif dari lingkungan sekitar dapat membantu beradaptasi dengan situasi dan keadaan yang tentunya berpengaruh terhadap tingkat kecemasan yang akan dialami. Namun, Kembali lagi pada masing-masing individu dimana terdapat beberapa individu yang memiliki tipe kepribadian introvert yang perlu mendapat perhatian yang lebih karena biasanya seseorang dengan tipe kepribadian introvert cenderung tertutup, sulit menerima perubahan atau beradaptasi, dan sering overthinking yang menyebabkan orang dengan tipe kepribadian introvert memiliki rata-rata tingkat kecemasan yang lebih tinggi. Berbeda dengan yang memiliki tipe kepribadian extrovert yang lebih bersikap terbuka dan mudah untuk beradaptasi (Ari Pamungkas, 2020). Tipe kepribadian introvert sangat memerlukan dukungan dari luar untuk dapat membantunya dalam beradaptasi dan mengatasi kecemasannya.

Faktor lainnya yang dapat mempengaruhi tingkat kecemasan pada remaja adalah religiusitas, yaitu nilai, keyakinan, sikap serta tingkah laku seseorang yang dapat mencerminkan perilaku beragama seseorang (Wahyuni et. al, 2020). Selain hubungan yang baik dengan sesama manusia, diperlukan juga hubungan yang baik pula dengan Tuhan kita sesuai dengan kepercayaan yang dimiliki. Karena dengan meningkatkan religiusitas, seseorang akan lebih optimis dan memiliki koping yang positif dalam menghadapi keadaan. Karena persiapan psikologis yang belum matang serta kurangnya pengalaman membuat kaum muda lebih rentan terhadap stress dan kecemasan (Febriyanti \& Mellu, 2020; Wardiani et. al, 2020). Jenis kelamin juga dapat mempengaruhi tingkat kecemasan seseorang. Perempuan memiliki resiko untuk mengalami kecemasan yang lebih tinggi dibandingkan dengan laki-laki (Febriyanti \& Mellu, 2020; Wahyuni et. al, 2020; Wardiani et. al, 2020; Aji et. al, 2021; Puspita et. al, 2021; Pratiwi \& Sukarta, 2020).

Kecemasan yang terjadi pada remaja dapat berdampak pada kurangnya tidur, kesulitan untuk fokus, mudah lupa, meningkatnya iritabilitas dan mudah marah (Fitria \& Ifdil, 2020; Yulianti \& Sari, 2020). Remaja yang memiliki pengetahuan lebih baik terkait dengan pandemic covid-19 memiliki tingkat kecemasan yang relative lebih ringan namun, masih tetap ada remaja yang memiliki tingkat kecemasan yang sedang bahkan berat sekalipun memiliki pengetahuan yang baik. Bahkan dengan pengetahuan yang lebih baik, bisa saja lebih banyak laki-laki yang mengalami kecemasan daripada perempuan 
(Suwandi \& Malinti, 2020). Maka dalam hal ini, koping masing-masing individu ketika menghadapi masalah berperan dalam perbedaan diatas.

\section{SIMPULAN}

Pandemi covid-19 sudah banyak menimbulkan stress dan kecemasan di kalangan remaja. Walaupun banyak remaja yang dapat mengatasi rasa cemas mereka, namun tidak sedikit pula yang masih belum bisa mengatasi rasa cemas mereka. Remaja dengan tingkat kecemasan yang ringan biasanya memiliki pengetahuan atau mengetahui dengan baik informasi terkait dengan pandemic covid-19 serta memiliki koping individu yang baik. Memiliki pengetahuan yang baik memang dapat mengurangi tingkat kecemasan namun, perlu juga diimbangi dengan kepatuhan terhadap protocol-protokol kesehatan yang telah ditetapkan untuk menghindari hal-hal yang tidak diinginkan. Walaupun selama masa pandemic ini diharuskan untuk menerapkan physical distancing, namun bukan berarti harus memutuskan hubungan sosial. Sangat perlu adanya rasa peduli, saling perhatian, belarasa, tolong menolong, dan saling menyemangati guna mempererat hubungan yang dibatasi oleh jarak ini. Dalam hal ini, perlu bantuan dan dukungan dari semua pihak baik dari lingkungan, keluarga dan bahkan diri sendiri untuk dapat meningkatkan kesehatan mental dalam memerangi pandemic covid-19 secara efektif.

\section{DAFTAR PUSTAKA}

Agus Purwanto, R. P. (2020). Studi Eksploratif Dampak Pandemi COVID-19 Terhadap Proses Pembelajaran Online di Sekolah Dasar (Vol. II). EduPsyCouns: Journal of Education, Psychology and Counseling. Retrieved from https://ummaspul.ejournal.id/Edupsycouns/article/vie w/397

Ahmad Sabir, M. P. (2016). Gambaran Umum Persepsi Masyarakat Terhadap Bencana Di Indonesia (Vol. V). Jurnal Ilmu Ekonomi dan Sosial.

Andre Setya Aji, S. T. (2020). Pengatuh Virtual Reality Terhadap Tingkat Kecemasan Mahasiswa Dalam Menghadapi Tugas Akhir Di Masa Pandemi Covid-19. Universitas Kusuma Husada Surakarta.

Astrid Dinda Wahyu Ilahi, V. R. (2021). The Level of Anxiety of Students during the Covid-19 Pandemic: Tingkat Kecemasan Mahasiswa di Masa Pandemi Covid-19 (Vol. I). Proceding of Inter-Islamic University Conference on Psychology.

Dadan Sumara, S. H. (2017). Kenakalan Remaja Dan Penanganannya (Vol. IV). Jurnal Penelitian \& PPM.

Devra Jovana Clarissa Suryaatmaja, I. S. (2020). Hubungan Tingkat Kecemasan Terhadap Sikap Remaja Akibat Pandemik Covid19 (Vol. II). MANUJU: MALAHAYATI NURSING JOURNAL.

Dhini Amynarti Wardiani, S. T. (2020). Gambaran Tingkat Kecemasan Pada Mahasiswa Keperawatan Universitas Kusuma Husada Surakarta Saat Menjalani Skripsi Pada Masa Pandemi Covid-19. Universitas Kusuma Husada Surakarta. 
Dona Fitri Annisa, I. (2016). Konsep Kecemasan(Anxiety)pada Lanjut Usia (Lansia) (Vol. V). KONSELOR.

Erna Febriyanti, A. M. (2020). Tingkat Kecemasan Mahasiswa Keperawatan (Vol. XI). Jurnal Ilmiah Ilmu Keperawatan. Retrieved from https://stikesnhm.e-journal.id/NU/index

Gheralyn Regina Suwandi, E. M. (2020). Hubungan Tingkat Pengetahuan Dengan Tingkat Kecemasan Terhadap Covid-19 Pada Remaja Di SMA Advent Balikpapan (Vol. II). Manuju : Malahayati Nursing Journal.

Imam Mahfud, A. G. (2020). Survey Of Student Anxiety Levels During The Covid-19 Pandemic (Vol. IV). Jurnal Pendidikan Jasmani, Olahraga dan Kesehatan. doi:https://doi.org/10.33503/jp.jok .v4i1.1103

Indri Wahyuni, S. R. (2020). Hubungan Tingkat Religiusitas Dengan Tingkat Kecemasan Mahasiswa Di Masa Pandemi Covid-19 (Vol. XIII). Jurnal Kesehatan Al-Irsyad.

Irma Maya Puspita, A. W. (2021). Gambaran Kecemasan Dan Kepatuhan Remaja Putri Terhadap Kebiasaan Baru Pada Masa Pandemi Covid-19 Di Surabaya (Vol. V). Journal of Midwifery Science.

Linda Fitria, I. I. (2020). Kecemasan remaja pada masa pandemi Covid -19 (Vol. VI). Jurnal EDUCATIO (Jurnal Pendidikan Indonesia). doi:http://dx.doi.org/10.29210/120 202592
MENDIKBUD. (17 Maret 202). Pembelajaran secara Daring dan Bekerja dari Rumah untuk Mencegah Penyebaran Covid-19. Retrieved from https://www.kemdikbud.go.id/mai n/blog/2020/03/se-mendikbudpembelajaran-secara-daring-danbekerja-dari-rumah-untukmencegah-penyebaran-covid19

Pamungkas, A. (2020). Tipe Kepribadian Ektrovert-Introvert dan Kecemasan (Vol. I). Jurnal Studi Keislaman. Retrieved from http://e-journal.iain-

palangkaraya.ac.id/index.php/sya ms

RI, K. K. (2015). SITUASI KESEHATAN REPRODUKSI REMAJA. KEMENKES. Retrieved from https://pusdatin.kemkes.go.id/reso urces/download/pusdatin/infodati n/infodatin-reproduksi-remaja.pdf

Safira, A. M. (2021). Pengaruh Fungsi Keluarga Dan Pendapatan Keluarga Terhadap Tingkat Kecemasan Remaja Di Era Pandemi Covid-19. Universitas Muhammadiyah Surakarta.

Sri Adi Widodo, L. R. (2017). Analisis Faktor Tingkat Kecemasan, Motivasi Dan Prestasi Belajar Mahasiswa (Vol. I). Jurnal Taman Cendekia.

Syami Yulianti, L. Y. (2021). Hubungan Pengetahuan Dan Perilaku Dengan Tingkat Kecemasan Remaja Terhadap Covid-19 Pada Siswa Di Pesantren Pancasila Kota Bengkulu (Vol. VII). Scientific Journal of Midwifery. 
Wilda Rezki Pratiwi, A. S. (2020). Hubungan Pemberitaan Media Sosial Terhadap Tingkat Kecemasan Perempuan Pada Masa Pandemi Covid-19. Seminar Nasional Kesehatan Masyarakat.

Zulfa Harirah MS, A. R. (2020). Merespon Nalar Kebijakan
Negara Dalam Menanggapi Pandemi Covid-19 Di Indonesia (Vol. VII). Jurnal Ekonomi dan Kebijakan Publik Indonesia. doi:https://doi.org/10.24815/ekapi .v7i1.17370 